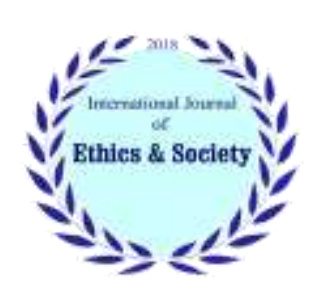

International Journal of Ethics \& Society (IJES)

Journal homepage: $\underline{\text { www.ijethics.com }}$

Vol. 2, No. $3(\mathbf{2 0 2 0})$

(Original article)

\title{
Organizational Strategies Model of Employee Performance Based on the Organizational Justice
}

\author{
Mahdi Moslehi ${ }^{\mathrm{a}}$, Sanjar Salajegheh ${ }^{\mathrm{b} *}$, Masoud Pourkiyani ${ }^{\mathrm{b}}$ \\ a) Dept. of Management, University of Payam-e-Noor, Tehran, Iran. \\ b) Dept. of Public Management, Islamic Azad University, Kerman Branch, Kerman, Iran.
}

\section{Abstract}

Background: The policy focuses on what the government is actually doing in practice, not just what it has proposed or intends to do, and distinguishes the policy from a decision that is merely a specific option among other options. The present study aimed to provide a model of organizational performance of employees based on organizational justice in Payam-e-Noor University.

Method: The present study was formed with a mixed approach. In the qualitative section of the statistical population, there were experts in the field of policy-making and management of Payam-e-Noor University of Hormozgan province, 15 of whom were selected as members of the panel group through homogeneous qualitative sampling method. The research tool was an interview. In a small part of the statistical population, all managers and staff of Payam-e-Noor University of Hormozgan province were approximately 400 people, of which 200 people were selected by stratified random sampling. A researcher-made questionnaire was used to collect information. To analyze the data in the qualitative part, the grounded theory was used and in the quantitative part, structural equations were used.

Results: The results show that the topics of the research are 6 main variables of the research including; gender justice, protectionist perspective, empowering attitude, confidence building, ethics and social commitment. After identifying the topics, the categories of analysis were defined. Thus, in this study, 23 main categories were defined and finally the research model had a suitable fit.

Conclusion: The performance of employees in an organization is one of the most important factors increasing the efficiency of the organization and its effectiveness and the most important channel to achieve optimal performance of employees is organizational justice.

Keywords: Organizational strategies, Employee performance, Organizational justice

* Corresponding Author: Email: sanjarsalajeghaeh@yahoo.com

Received: 24 Nov 2020

Accepted: 30 Dec 2020 


\section{Introduction}

An examination of the policy-making process shows that several factors are involved in the adoption and implementation of policies. In this case, there are factors that are involved within the policymaking administrative system and occur within the policy-making internal environment. But there are other factors that are outside the policy system and in its external environment. Although these factors are outside the policy-making environment, but they affect the policy-making process and direct it in the direction they want (1). The results show that factors such as values, information systems, media, policy transfer, social structures and institutions, resources and facilities, the public and public opinion, policy research centers and influential groups are the most important factors available. They are in this environment. Lack of a coherent system of decision-making and decision-making causes consequences that range from the lack of order in the cultural workflow of society and related social systems, to the distortion of the system of division of social and cultural work (2). Due to the lack of coherent foundations in the field of organizational policy, also because policy-making for the organization is a complex process and takes a long time to implement, the development of clear, unambiguous, comprehensive and reliable frameworks to ensure its basic necessities It is considered and for this reason, identifying its concepts and basic principles and providing a comprehensive and accurate definition of its constituent elements are among the issues that should be seriously considered. Since organizational policy determines planning for organizations at the macro level and how the organization operates depends on it, it is necessary to define it precisely and what it is, as well as the elements involved in it. Identify and it's various stages accurately (3). Human resources, as one of the main factors and institutions of any organization, has a significant role in the quality and quantity of the organization's outputs. The growth and development of human resources and increasing the skills, creativity and knowledge of the workforce at all levels of the organization has been a strategic priority for managers since the 1990s (4). Job performance is one of the variables that has received a lot of attention in many developed countries. Psychologists consider job performance as a product of human behaviors and believe that motivations and needs affect the performance of individuals and ultimately economic growth and development (5).

Organizational justice is an important part of social interactions and effectiveness in organizations and is an important issue for individuals. Since this concept is necessary for individual and organizational outcomes and processes, not only philosophers and social commentators but also management scientists are interested in studying and understanding such a subject for a long time (6). The life and continuity of any social organization and institution depends on the existence of a strong link between its constituent elements. This link is affected by the degree of justice in that organization. Evaluating people's responses to what they get from working in the organization versus what they provide to the organization has been a very social issue in the field of justice. Researchers consider organizational justice as the perception of individuality of fair or unfair treatment of employees of the organization (7). Justice is an important motivator for employees, and when people feel unfair, their morale plummets. At this time, most employees are willing to leave the job and may even confront the organization. Instead, appropriate and fair behavior fosters talent, increases commitment and desire to stay in the organization, and contributes significantly to increasing unifying humanistic behaviors. It is beyond the official position of the organization in any position. When people feel that they are being treated unfairly in the organization, their obligations are reduced, their performance is reduced, and they are less likely to cooperate in work (8). Most research on justice acknowledges that there are three basic types of justice: distributive, procedural, and interactive (9). Distributive justice refers to the understanding of outcomes (job outcomes) that are consistent with the implicit norms of allocation. Procedural justice refers to the perceived fairness of outcome-determining processes. And interactive justice is related to the perception of organizational 
practices. In fact, it refers to communication (10). Accordingly, organizational justice is the result of employees' conscious study of justice in their exchanges and relationships with their organization (11). In the present era, when our country is going through a period of construction and all the attention of the people of the society is focused on the development, improvement and promotion of the level of information, knowledge and technology; Looking at developed countries, it can be seen that these countries have paid more attention to the job performance of their employees and the perception of justice by their employees, and therefore, assuming that one of the major factors of organizational justice and proper performance in Payam-e-Noor University, can be properly formulated. Be the patterns of organizational policies, and given that no research has yet been done on the presentation of the pattern of organizational policies of employees based on organizational justice. Therefore, in the present study, following the elimination of this gap, it seeks to provide a model of organizational mesh performance of employees based on organizational justice in Payam-e-Noor University.

\section{Material and Methods}

In terms of results, this research is considered as part of development research and in terms of purpose, this research is part of applied research. The present study was formed with a mixed approach. In the qualitative part, the grounded theory approach was used. The statistical population was the policy and management experts of Payam-e-Noor University of Hormozgan province, 15 of whom were selected as members of the panel group through homogeneous qualitative sampling method. The data collection tool in the qualitative section was based on the method of critical evaluation and review of similar articles and researches, which were designed using component scoring of organizational mesh performance of employees based on organizational justice in Payam-e-Noor University through a score checklist and the foundation data method. accepted. To do this, according to previous arrangements, designed checklists were provided to panel members (experts). In a small part of the statistical population, all managers and staff of Payam-e-Noor University of Hormozgan province were approximately 400 people. According to the size of the population and the sampling formula, the minimum sample size was 196 people. In order to be more confident, 200 people were selected, and in the end, only 185 of them returned the questionnaire. In this study, stratified random sampling method has been used. A researcher-made questionnaire of qualitative section was used to collect information, the validity and reliability of which are presented in the findings section. . To analyze the data in the qualitative part of the grounded theoretical approach and in the quantitative part of this study from descriptive statistics (statistical tables, matrix tables, shapes, etc.), and inferential statistics (comparison of the mean of independent samples, analysis of variance, post hoc tests and multivariate regression) were used. SPSS22 and Lisrel 8.8 software were used for quantitative analysis of research data and model fit.

\section{Results}

After determining the research variables, the units of analysis (theme, category and indicators) were identified. In the first stage, the themes of this research were determined. These topics include 6 main research variables including; Gender justice, protectionist perspective, empowering attitude, confidence building, ethics and social commitment. After identifying the topics, the categories of analysis were defined. In such a way that each theme includes categories. Thus, in this study, 23 main categories have been defined. According to the questions, themes and categories defined, the answers of each of the respondents were placed under one of the categories, and finally, after summarizing the answers related to each of the experts, the options related to Organizational mesh performance of employees based on organizational justice was determined. Similarly, other open-ended responses and responses obtained from supplementary interviews were categorized and analyzed, and finally the sum of the analyzed responses to determine the factors 
of organizational mesh performance of employees based on organizational justice in Payam-e-Noor University were used. Table 2 presents its themes, categories, and indicators. It should be noted that in the table, only the indicators that have the highest frequency and repetition and have been more important in identifying research categories are mentioned. In practice, the researcher has used more markers to identify the content of respondents' responses.

Table1: Research content, categories and indicators

\begin{tabular}{|c|c|c|}
\hline Content & Category & Indicator \\
\hline \multirow[t]{4}{*}{ Gender justice } & Life changes & $\begin{array}{l}\text { Lack of money and even money for renting a house, not hav- } \\
\text { ing a good job, not having insurance from the employer, not } \\
\text { having enough income today }\end{array}$ \\
\hline & Silence and withdrawal & $\begin{array}{l}\text { Low level of culture, fear of expressing ideas, fear of being } \\
\text { fired, fear of not being promoted, indifference to work issues, } \\
\text { lack of concern for organizational issues, }\end{array}$ \\
\hline & Neurosis & $\begin{array}{c}\text { Emotional problems, work-type depression, weak faith, confu- } \\
\text { sion in not knowing your role in the organization, boredom, } \\
\text { despair }\end{array}$ \\
\hline & Labor exploitation & $\begin{array}{l}\text { Improper hard work, bad working conditions, employer } \\
\text { threats, harassment by co-workers, }\end{array}$ \\
\hline \multirow[t]{3}{*}{$\begin{array}{l}\text { Supportive } \\
\text { viewpoint }\end{array}$} & Family support & $\begin{array}{l}\text { Helping to care for and raise children, family support, } \\
\text { strengthening emotional support, changing prejudices and } \\
\text { misconceptions about women's employment and working in } \\
\text { the family, }\end{array}$ \\
\hline & Organizational support & $\begin{array}{c}\text { Facilitate lending and facilities, develop economic protection } \\
\text { laws, establish support funds }\end{array}$ \\
\hline & Community support & $\begin{array}{l}\text { Strengthening the vision and motivation to serve in the com- } \\
\text { munity, supporting the community from the type of work of } \\
\text { individuals, helping support organizations, not giving up after } \\
\text { creating employment and financial support by the support or- } \\
\text { ganization, changing the attitude of the community from tar- } \\
\text { geted material assistance to job creation }\end{array}$ \\
\hline \multirow[t]{3}{*}{$\begin{array}{l}\text { Empowering } \\
\text { attitude }\end{array}$} & Capacity Building & $\begin{array}{c}\text { Skills training, improving work style, nurturing talents and } \\
\text { strengthening innovation, spreading the culture of reading and } \\
\text { using mass media, }\end{array}$ \\
\hline & Skills enhancement & $\begin{array}{l}\text { Technical-vocational training, legal-economic training, } \\
\text { knowledge of modern technologies }\end{array}$ \\
\hline & Self-sufficiency & $\begin{array}{l}\text { Ensuring security in the workplace, strengthening risk-taking } \\
\text { and encouraging independence, changing people's attitudes to- } \\
\text { wards themselves and creating morale in them, creating fresh- } \\
\text { ness in people through participation in the organization, help- } \\
\text { ing to improve relationships with colleagues, creating a sense } \\
\text { of self-efficacy }\end{array}$ \\
\hline \multirow[t]{3}{*}{ Trust building } & talent discovery & $\begin{array}{l}\text { Improving the level of knowledge, skill orientation, empower- } \\
\text { ment, willingness to do new things, increasing self-efficacy }\end{array}$ \\
\hline & Thinking & $\begin{array}{l}\text { Self-awareness, acceptance of new ideas, elimination of fear of } \\
\text { the unspoken, organizational acceptance, intellectual inde- } \\
\text { pendence, strengthening of talents, }\end{array}$ \\
\hline & Self-esteem & $\begin{array}{l}\text { Strengthen self-esteem, attention to need, appropriate support, } \\
\text { strengthen self-confidence, sense of worth at work, }\end{array}$ \\
\hline \multirow[t]{3}{*}{ Ethics oriented } & progressive & $\begin{array}{l}\text { Intellectual independence, financial independence, hopeful for } \\
\text { the future, productive, work-loving, indefatigable }\end{array}$ \\
\hline & Innovative & Aware of opportunities, risk-taking, creative, eager to change \\
\hline & Trustworthy & $\begin{array}{l}\text { Ethical, resistant to hardships, has a strong religious and doc- } \\
\text { trinal perspective, autonomous, self-control }\end{array}$ \\
\hline
\end{tabular}

40

Available at: www.ijethics.com 


\begin{tabular}{|c|c|c|}
\hline \multirow[t]{7}{*}{$\begin{array}{l}\text { Social } \\
\text { commitment }\end{array}$} & Responsibility & $\begin{array}{l}\text { Creativity training, emphasis on responsibility, regular compe- } \\
\text { tition, sense of trust }\end{array}$ \\
\hline & Love to work & $\begin{array}{c}\text { Changing work style, reducing stress and mental tensions, pro- } \\
\text { moting happiness by modifying beliefs and making them ra- } \\
\text { tional, developing talent and growing up with happiness and } \\
\text { vitality }\end{array}$ \\
\hline & Error reduction & $\begin{array}{l}\text { Organizational support, goal-oriented training, providing a } \\
\text { suitable environment for well-being and peace }\end{array}$ \\
\hline & Coherence & $\begin{array}{l}\text { Strengthen harmony and self-adaptation, sense of mutual re- } \\
\text { sponsibility, unity in the personality of individuals, participa- } \\
\text { tion, increase trust }\end{array}$ \\
\hline & Have a long horizon & $\begin{array}{l}\text { Optimism for the future, strengthening hope and self-confi- } \\
\text { dence, strengthening a positive attitude, strengthening faith } \\
\text { and belief }\end{array}$ \\
\hline & Preserving the value of work & $\begin{array}{l}\text { Emphasis on labor rights, observance of justice and equality, } \\
\text { giving opportunities for self-confidence, attention to existen- } \\
\text { tial values, }\end{array}$ \\
\hline & Self-esteem & $\begin{array}{l}\text { Not to be isolated, to give opinions, to accept new ideas, to } \\
\text { give important opportunities, to respect new ideas }\end{array}$ \\
\hline
\end{tabular}

In order to confirm the validity of the researchermade questionnaires, the content validity method (CVR) was used, based on which 15 panel members were asked to give the necessary points to each component. The results obtained showed that the content validity of the research components was confirmed due to the fact that the CVR value of the scale is larger than 0.50 . In order to determine the reliability of the questionnaires, Cronbach's alpha coefficient was used and the results according to the table below show that all components of the research are higher than 0.7 . In this study, the mean test of a population was used to determine the appropriateness of the variables. According to this test, wherever the significance number is greater than 0.05 , there is no significant difference between the status of the variable and the average and the variable will have a moderate status, but if the significance number is less than 0.05 , it means that between There is a significant difference between the variable status and the considered average.

Table2: Reliability coefficient of each ques-
tionnaire variable
\begin{tabular}{|l|l|l|}
\hline Variables & $\begin{array}{l}\text { Cronbach's } \\
\text { alpha }\end{array}$ & Results \\
\hline Gender justice & $0 / 855$ & Accepted \\
\hline Supportive viewpoint & $0 / 902$ & Accepted \\
\hline Empowering attitude & $0 / 866$ & Accepted \\
\hline Trust building & $0 / 877$ & Accepted \\
\hline Ethics oriented & $0 / 811$ & Accepted \\
\hline Social commitment & $0 / 762$ & Accepted \\
\hline
\end{tabular}

If the upper and lower limit values are positive, the status of the variables is appropriate, and if the upper and lower limits are negative, the status of the variables is inappropriate. Table 3 shows the results of this test

Table 3: Results of research indicators in terms of appropriateness

\begin{tabular}{|c|c|c|c|c|c|c|}
\hline \multirow[t]{2}{*}{ Variables } & \multirow[t]{2}{*}{$\mathbf{T}$} & \multirow[t]{2}{*}{ df. } & \multirow[t]{2}{*}{ Sig. } & \multirow[t]{2}{*}{ Mean d. } & \multicolumn{2}{|c|}{$\alpha=0.05$} \\
\hline & & & & & Up & Down \\
\hline Gender justice & $3 / 499$ & 184 & 0/001 & $0 / 269$ & $0 / 421$ & $0 / 117$ \\
\hline Supportive viewpoint & $6 / 292$ & 184 & $0 / 000$ & $0 / 470$ & $0 / 617$ & $0 / 322$ \\
\hline Empowering attitude & $9 / 643$ & 184 & $0 / 000$ & $0 / 790$ & $0 / 952$ & $0 / 628$ \\
\hline Trust building & $6 / 471$ & 184 & $0 / 000$ & $0 / 584$ & $0 / 763$ & $0 / 406$ \\
\hline Ethics oriented & $3 / 276$ & 184 & $0 / 001$ & $0 / 324$ & $0 / 520$ & $0 / 128$ \\
\hline Social commitment & $5 / 726$ & 184 & $0 / 000$ & $0 / 518$ & $0 / 697$ & $0 / 339$ \\
\hline
\end{tabular}


Table4: Results of factor analysis of selected item questions

\begin{tabular}{|c|c|c|c|c|}
\hline Factors & dimension & Question & $\begin{array}{c}\text { Standard } \\
\text { factorial load }\end{array}$ & Sig. \\
\hline \multirow{12}{*}{ Gender justice } & \multirow[t]{3}{*}{ Life changes } & Q1 & $0 / 79$ & $16 / 98$ \\
\hline & & Q2 & $0 / 76$ & $12 / 30$ \\
\hline & & Q3 & $0 / 62$ & $16 / 65$ \\
\hline & \multirow[t]{3}{*}{ Silence and withdrawal } & Q4 & $0 / 78$ & $16 / 73$ \\
\hline & & Q5 & $0 / 78$ & $17 / 86$ \\
\hline & & Q6 & $0 / 82$ & $16 / 70$ \\
\hline & \multirow[t]{3}{*}{ Neurosis } & Q7 & $0 / 78$ & $16 / 70$ \\
\hline & & Q8 & $0 / 76$ & $15 / 87$ \\
\hline & & Q9 & $0 / 82$ & $18 / 08$ \\
\hline & \multirow[t]{3}{*}{ Labor exploitation } & Q10 & $0 / 61$ & $12 / 05$ \\
\hline & & Q11 & $0 / 64$ & $12 / 67$ \\
\hline & & Q12 & $0 / 61$ & $11 / 95$ \\
\hline \multirow[t]{9}{*}{ Supportive viewpoint } & \multirow[t]{3}{*}{ Family support } & Q13 & $0 / 61$ & $12 / 05$ \\
\hline & & Q14 & $0 / 63$ & $12 / 34$ \\
\hline & & Q15 & $0 / 56$ & $10 / 89$ \\
\hline & \multirow{3}{*}{ Organizational support } & Q16 & $0 / 53$ & $10 / 05$ \\
\hline & & Q17 & $0 / 50$ & $9 / 35$ \\
\hline & & Q18 & $0 / 58$ & $11 / 17$ \\
\hline & \multirow[t]{3}{*}{ Community support } & Q19 & $0 / 75$ & $15 / 39$ \\
\hline & & Q20 & $0 / 76$ & $15 / 73$ \\
\hline & & Q21 & $0 / 73$ & $15 / 02$ \\
\hline \multirow[t]{9}{*}{ Empowering attitude } & \multirow[t]{3}{*}{ Capacity Building } & Q22 & $0 / 75$ & $15 / 37$ \\
\hline & & Q23 & $0 / 75$ & $15 / 62$ \\
\hline & & Q24 & $0 / 70$ & $13 / 95$ \\
\hline & \multirow[t]{3}{*}{ Skills enhancement } & Q25 & $0 / 55$ & $10 / 50$ \\
\hline & & Q26 & $0 / 61$ & $11 / 76$ \\
\hline & & Q27 & $0 / 51$ & $9 / 59$ \\
\hline & \multirow[t]{3}{*}{ Self-sufficiency } & Q28 & $0 / 78$ & $16 / 36$ \\
\hline & & Q29 & $0 / 76$ & $15 / 87$ \\
\hline & & Q30 & $0 / 60$ & $11 / 63$ \\
\hline \multirow[t]{9}{*}{ Trust building } & \multirow[t]{3}{*}{ Talent discovery } & Q31 & $0 / 76$ & $15 / 83$ \\
\hline & & Q32 & $0 / 76$ & $15 / 82$ \\
\hline & & Q33 & $0 / 79$ & $16 / 84$ \\
\hline & \multirow[t]{3}{*}{ Thinking } & Q34 & $0 / 77$ & $16 / 18$ \\
\hline & & Q35 & $0 / 75$ & $15 / 48$ \\
\hline & & Q36 & $0 / 82$ & $17 / 74$ \\
\hline & \multirow[t]{3}{*}{ Self-esteem } & Q37 & $0 / 61$ & $11 / 80$ \\
\hline & & Q38 & $0 / 64$ & $12 / 51$ \\
\hline & & Q39 & $0 / 61$ & $11 / 78$ \\
\hline \multirow[t]{9}{*}{ Ethics oriented } & Progressive & Q40 & $0 / 61$ & $11 / 80$ \\
\hline & & Q41 & $0 / 64$ & $12 / 57$ \\
\hline & & Q42 & $0 / 61$ & $11 / 88$ \\
\hline & Innovative & Q43 & $0 / 49$ & $9 / 19$ \\
\hline & & Q44 & $0 / 33$ & $5 / 87$ \\
\hline & & Q45 & $0 / 55$ & $10 / 51$ \\
\hline & Trustworthy & Q46 & $0 / 47$ & $8 / 59$ \\
\hline & & Q47 & $0 / 58$ & $10 / 97$ \\
\hline & & Q48 & $0 / 74$ & $15 / 10$ \\
\hline Social commitment & Responsibility & Q49 & $0 / 75$ & $15 / 36$ \\
\hline & & Q50 & $0 / 75$ & $15 / 16$ \\
\hline & & Q51 & $0 / 72$ & $14 / 43$ \\
\hline & Love to work & Q52 & $0 / 74$ & $15 / 04$ \\
\hline & & Q53 & $0 / 77$ & $13 / 88$ \\
\hline & & Q54 & $0 / 56$ & $10 / 52$ \\
\hline & Error reduction & Q55 & $0 / 53$ & $12 / 25$ \\
\hline & & Q56 & $0 / 53$ & $9 / 86$ \\
\hline
\end{tabular}




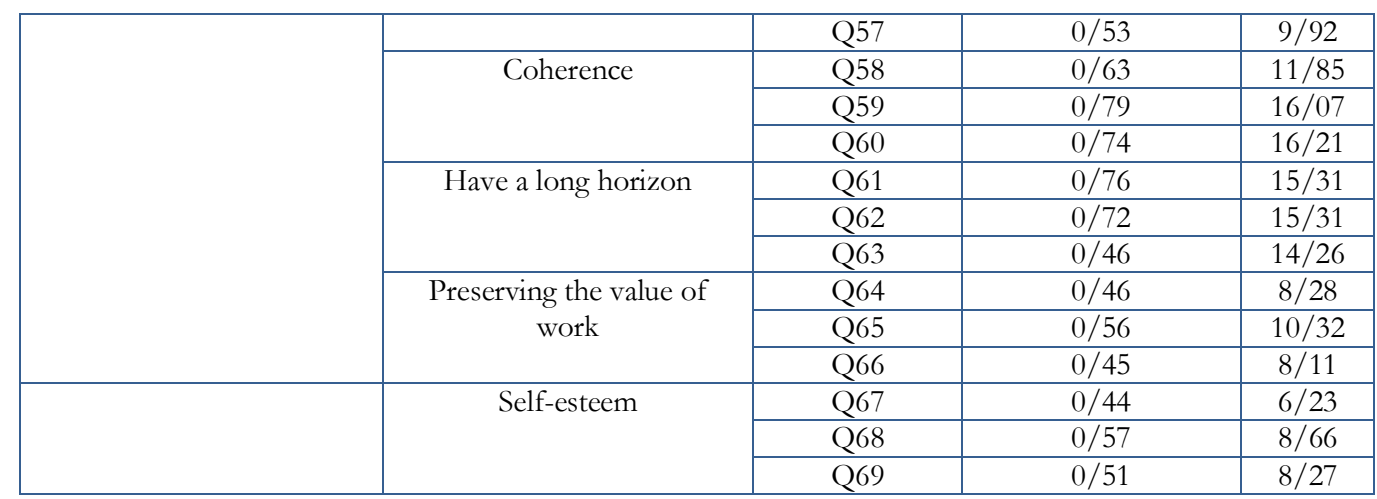

Since it is statistically suggested that factors with a value of regression weight (factor load) more than 0.40 are considered significant and acceptable, so all regression weights in The studied model has values greater than 0.40 and all critical ratios ( $t$ value) are significant at the level of $\mathrm{P}<0.01$; Therefore, all the considered factors except the mentioned factors have been confirmed and the overall fit indicates a good fit of the studied measurement model with the observed data.

Table5: Model fit indicators

\begin{tabular}{|l|l|l|l|} 
Indicator & Rate & \multicolumn{1}{l|}{$\begin{array}{l}\text { Accepta- } \\
\text { ble range }\end{array}$} & Result \\
\hline X2/df & $2 / 57$ & $\begin{array}{l}\text { Between 1- } \\
5\end{array}$ & Acceptable \\
\hline NFI & $0 / 90$ & $0.9>$ & Acceptable \\
\hline GFI & $0 / 90$ & $0.9>$ & Acceptable \\
\hline AGFI & $0 / 63$ & Near to 1 & $\begin{array}{l}\text { Unaccepta- } \\
\text { ble }\end{array}$ \\
\hline TLI \& NNFI & $0 / 91$ & $0.9>$ & Acceptable \\
\hline IFI & $0 / 90$ & $0.9>$ & Acceptable \\
\hline CFI & $0 / 90$ & $0.9>$ & Acceptable \\
\hline PNFI & $0 / 78$ & $0 / 6>$ & Acceptable \\
\hline RMSEA & $0 / 068$ & $0 / 08<$ & Acceptable \\
\hline RFI & $0 / 92$ & $0 / 9>$ & Acceptable \\
\hline RMR & $0 / 13$ & Near Zero & $\begin{array}{l}\text { Unaccepta- } \\
\text { ble }\end{array}$ \\
\hline
\end{tabular}

According to the LISRL output shown in Table 5, the calculated df / $2 \mathrm{X}$ is 2.57 , the presence of $\mathrm{df}$ / $2 \mathrm{X}$ less than 3 indicates a good fit of the model. Also, the root of the error of mean squared approximation (RMSEA) must be less than 0.08, which in the proposed model is equal to 0.068. According to the indicators and outputs of LISREL software, it can be said that the data are consistent with the model, and the indicators presented indicate that in general, the status of the organizational mesh line provided is a good model and the data The so-called experimental ones fit in well.

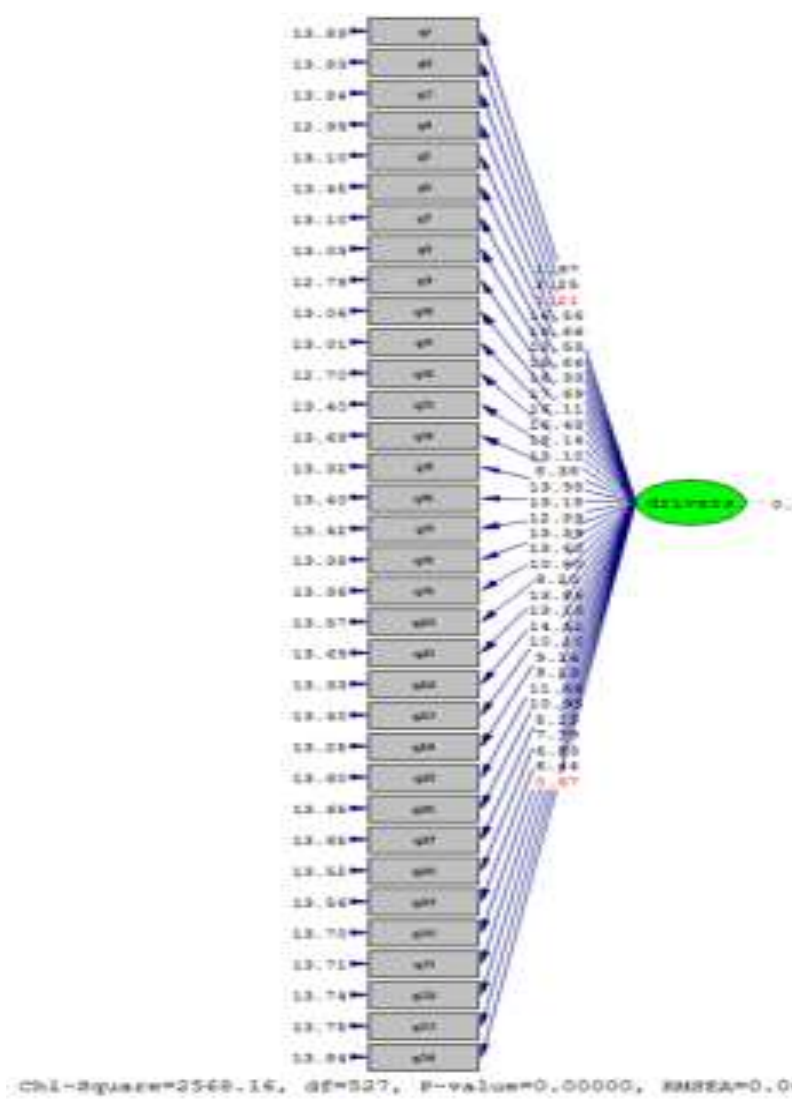

Figure. 1: Confirmatory factor analysis in standard mode of organizational policy variable 


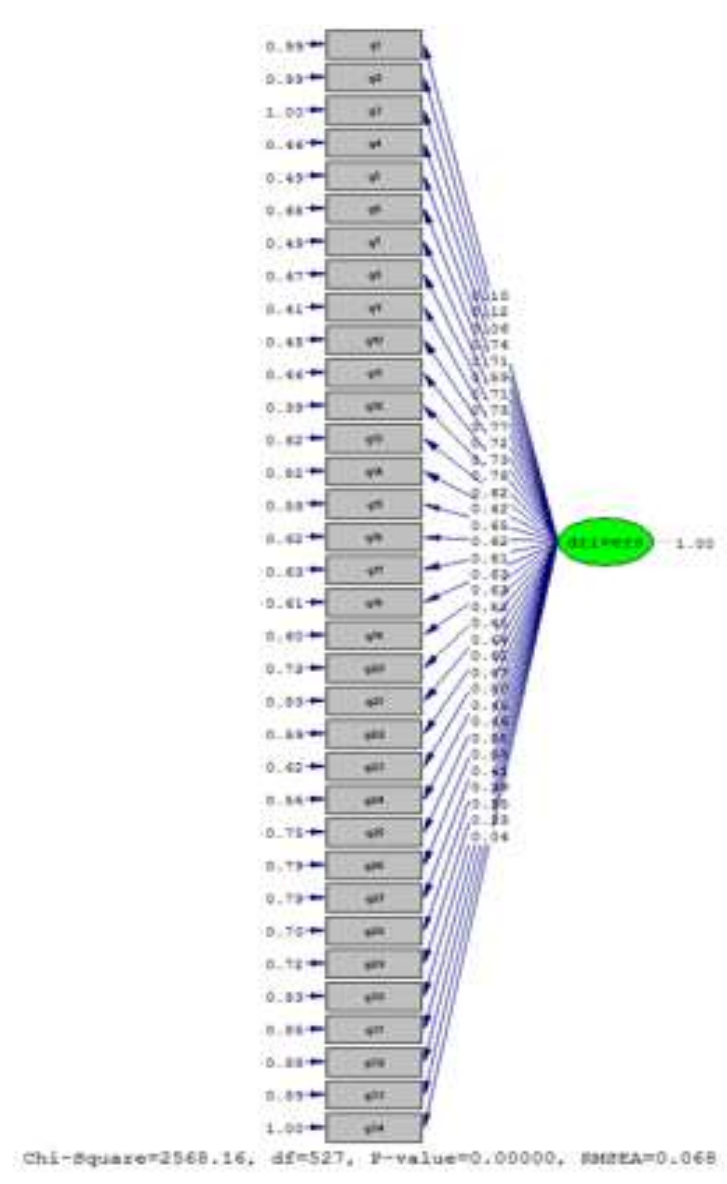

Figure. 2: Confirmatory factor analysis in t-value of organizational policy variable

\section{Discussion}

The results of the analysis of the interviews show that many empirical factors affect the organizational mesh line, so that the role of employees and their functional tasks is a very effective factor for the organizational mesh line based on organizational performance and justice. This result is consistent with the results of many other studies (12, 13).

Based on the results of the present study, gender justice, protectionist view, empowering attitude, trust building and ethics and social commitment are the most important issues in organizational policy that can increase employee performance and establish organizational justice. Slowly each of the components discussed in various studies have been emphasized and confirm the results of the present study (14-18).

It is therefore recommended:

- Organizations should pay special attention to human resources and skills development. Their manpower, skills and abilities will play a very effective role in creating a positive experience and provide a good mental background for employees' preferences.

- Organizations adopt appropriate performance policies because understanding the policy is important because many social programs are funded through public funding. These programs are shaped and influenced by policy. The people and the society expect the government to make good use of public resources and facilities. They expect the government to choose the best way to achieve the ultimate goals of the society. But what is observed in practice is that many of the policies formulated during the implementation phase have encountered problems. To find out why and how a particular outcome is achieved, a study of the policy, and especially the literature on policy implementation, provides an important perspective for awareness and understanding of implementation.

\section{Conclusion}

The growth and development of human resources and increasing the skills, creativity and knowledge of the workforce at all levels of the organization has been a strategic priority for managers since the 1990s. Job performance is one of the variables that has received a lot of attention in many developed countries. Psychologists consider job performance as a product of human behaviors and believe that motivations and needs affect people's performance and ultimately economic growth and development. The mission of management and the main goal of managers of any organization is the effective and efficient use of various resources and facilities such as labor, capital, materials, energy and information. In line with this mission, the optimal use of human resources (performance of human resources) is of particular importance because 
human beings, unlike other organizational resources, have intellect and authority and the manager cannot simply use it. More importantly, manpower is not only an organizational resource but also the only factor in employing other factors. This role becomes more important in grassroots organizations because human beings become the scene of work and related services. Now, if this person is motivated, capable and beneficial, he can use other resources in a good and desirable way and achieve various types of productivity and ultimately improve the performance of the organization. Motivation is one of the main problems of today's organizations is the poor performance of human resources in organizations. Obviously, the poor performance of the organization's employees should be corrected if observed and increase their efficiency and effectiveness of the organization. Poor performance has significant negative effects on the management and employees of the organization, which is unpleasant for both management and employees. Unfortunately, the current knowledge about how managers deal with poor performance of employees is very little. Perhaps one way to deal with poor employee performance and improve their performance is to pay attention to the way employees perceive justice. Organizational justice is an important part of social interactions and effectiveness in organizations and is an important issue for individuals. Since this concept is necessary for individual and organizational results and processes, not only philosophers and social commentators but also management scientists are interested in studying and understanding such a subject for a long time. The life and continuity of any social organization and institution depends on the existence of a strong link between its constituent elements. This link is affected by the degree of justice in that organization. Evaluating people's responses to what they get from working in the organization versus what they provide to the organization has been a very social issue in the field of justice. Researchers consider organizational justice to be an individual's perception of how fair or unfair the organization's employees treat them.

\section{Ethical Consideration}

Ethical issues (including plagiarism, informed consent, misconduct, data fabrication and/or falsification, double publication and/or submission, redundancy, etc.) have been completely observed by the authors.

\section{Acknowledgement}

Researchers consider it necessary to thank and appreciate all the colleague who helped us in this research.

\section{References}

1. Vigoda Gadot E (2007). Redrawing the boundaries of OCB? An empirical examination of compulsory extra-role behavior in the workplace. Joumal of Business and Psychology, 21 (3): 377-405.

2. Pourezat A, Ehsani-Moghadam N, Yazdani H, Faezeh K (2013). Comparative analysis of the role of various dimensions of justice in the organizational climate and organizational loyalty. Public Management, 5(1): 65-88. (In Persian).

3. Khajehnian D, Farhangi A, Hadavinia A (2009). Designing an interactive model of media management and new information and communication technologies. Communicational Researches, 16(4): 11-36. (In Persian).

4. Rahman Seresht H, Joneidi-Jafari M (2018). The effect of organizational justice on organizational citizenship behavior mediated by job commitment in project management. Journal of Management Studies, 27(87): 127-146. (In Persian).

5. Ghasemi AR (2014). Investigating the mediating role of organizational citizenship behavior on organizational justice and job performance. Organizational Culture Management, 12(1): 63-82. (In Persian).

6. Yeşil S, Dereli S (2013). An empirical investigation of the organizational justice, knowledge sharing and innovation capability. Procedia -Social and Behavioral Sciences, 75. 199-208.

7. Alvani S M, Sharifzadeh F (2006). Policy making process. 4th ed. Allameh Tabataba'i University Press (RA), Tehran/ Iran. (In Persian).

8. Seyyed Javadin SR, Abedi A, Yazdani HR, Valipour B (2013). Investigating the mediating role of organizational trust and commitment in the relationship between organizational justice and organizational citizenship behaviors in hospitals. Business Management, 5(1): 105-118. (In Persian). 
9. Atalay C, Özler D (2013). A research to determine the relationship between organizational justice and psychological ownership among non-family employees in a family business. Procedia - Social and Behavioral Sciences, 99.

10. Klendauer R, Deller J (2009). Organizational justice and managerial commitment in corporate mergers. Journal of Managerial Psychology, 24(1).

11. Lin, Ping-Yi, Maclennan S, Hunt N, Cox T (2015). The influences of nursing transformational leadership style on the quality of nurses' working lives in Taiwan: A cross-sectional quantitative study. BMC Nursing, 14 (10).

12. Naderi N, Hoveida R, Siadat A, Naderi MR (2010). Relation between organizational Justice with performance evaluation items among employees at Isfahan Refinery company. Educational Modern Perspectives, 5(2): 97-112. (In Persian).

13. Borg R, Toikka A, Primmer E (2015). Social capital and govemance: a social network analysis of forest biodiversity collaboration in Central Finland. Forest Policy and Economics, 50: $90-97$
14. Aryee S, Budhwar P, Chen Z (2002). Trust as a mediator of the relationship between organizational justice and work outcomes: test of a social exchange model. Journal of Organizational Behavior, 23(3): 267-285.

15. Li H, Bingham J, Umphress E (2007). Fairness from the top: perceived procedural justice and collaborative problem solving in new product development. Organization Science, 18(2): 200-216.

16. Niehoff B, Moorman R (1993). Justice as a mediator of the relationship between methods of monitoring and organizational citizenship behavior. Academy of Management Journal, 36(3): 527-556.

17. Tekleab A, Takeughi R, Taylor M (2005). Extending the chain of relationships among organizational justice social exchange, and employee reactions: the role of contract violations. Academy of Management Joumal, 48(1): 146-157.

18. Utami A, Bangun Y, Lantu D (2014). Understanding the role of emotional intelligence and trust to the relationship between organizational politics and organizational commitment. Procedia - Social and Behavioral Sciences, 115: 378 386. 